\title{
Social Policies and its Direct Impact on Poverty Reduction
}

\section{Buddhi Bahadur Thapa}

\section{Abstract}

Poverty is one of the major factors that bring obstacles in any kind of growth and development in any part of the world. The problem of poverty is complex in our country so there is a need of appropriate policies that can reduce social inequality and maintain social justice in Nepalese societies. Appropriate social policies can bring positive changes in the life of rural and urban poor. In this light, this article focuses on the role of social policies on poverty reduction and alleviation.

[Key words: poverty, social policy, social justice, poverty alleviation]

\section{Introduction}

It is widely believed that social policies have greater role in poverty alleviation and can have direct impact for social inequality and justice. Most of the development interventions are meant for poverty reduction. Although the development activities have been launching from more than five decades with different titles of the decades, name and jargon, the condition of the poor is not improved and the poverty is seen even more appalling condition in the developing countries. There have been unequal distributions of wealth, benefits, opportunities and other services in the societies. Due to this, the poor became poorer and rich became even richer. Most of the poor people live in rural areas and deprive of benefits of development. They lack land for the cultivation in which their livelihoods solely depend. Furthermore, there have been gradually increasing people's suffering and living under conditions because of natural disasters and due to the mismanagement. This scenario can be changed through the formulation and effective implementation of national social policies. Social policies can play a significant and direct role for reduction of poverty. Unless the social policies are not in favour of the poor, poverty seems to remain in the societies. In this essay I have tried to describe poverty and social policy in the context of Nepal. This essay has used both literature review and my 
Himalayan Journal of Sociology \& Anthropology-Vol. III

own experience while working in developing field in relation to poverty reduction and social policies.

\section{Poverty: Meaning, Causes and consequences}

Poverty has got a special place in today's development discourse. Although there is varied understanding about poverty but in simple words it is a situation where people have difficulties to fulfil their basic needs. It is not a uni-dimensional issue but covers many aspects such as economic, political, socio-cultural and so on. According to Burkey (1993), "Basic needs are those things that an individual must have in order to survive as a human being; these are clean air and water, adequate and balance food, security, rest, appropriate clothing and shelter.” (p. 3). There have been millions of people in the world who are suffering from lack of food and dying from the hunger. Furthermore, there has been a wide gap between rich and the poor countries. According to Nalli (Dec. 2004 - March 2005), “Everyday 799 million people in developing countries about $18 \%$ of the world's population go hungry.”(p. 4). Poverty is relative term and understood differently in different contexts. Basically poverty is the outcome of unjust social system (structural issue) which is based on unequal distribution of resources and benefits. Obviously it has become the cause of further deprivation through perpetuation of it.

In the context of Nepal, when we talk about poverty it is understood as absolute poverty where the masses do not have an access to and control over productive resources. The economy of is heavily dependent on agriculture. Around 32 per cent of total population are still below poverty level. Most of the poor people live in rural areas and their main source of income is peasantry. Many poor people in the rural areas lack basic goods and services such as food, clothes, shelter, safe drinking water, health and education. Unless the direct involvement of rural poor is included in the designing and implementation of agricultural development, it is impossible to address the poverty alleviation strategies in the developing countries 
including Nepal. As IFAD, (2001) estimates that three-quarters of the world's 1.2 billion poorest people earning less than one dollar per day and live and work in rural areas and that, even by 2020, this figure will remain high at 60 per cent.”(p. 89).

The largest number of world leaders gathered in New York in 2000 and discussed about the most critical issues which the world is facing in $21^{\text {st }}$ century, and come out with the key objectives of the Millennium Declaration. Among the Millennium goal and objectives the development and poverty reduction / eradication is considered as second goal in the world. According to Thomas (2000), “since 1995 development goals and targets have been reiterated in several areas related to poverty alleviation.”(p. 4). To achieve this goal it needs to make explicit social policies at the local and global level. As Escobar points out “ it is absolutely necessary that governments and international organisations take an active role in promoting and orchestrating the necessary efforts to overcome general backwardness and economic underdevelopment.”(1997 p. 86). Formulation of better social policies and genuine implementation of these policies are in the heart of poverty reduction.

\section{Social Policies and Their Role in Poverty Reduction}

In simple words policy can be defined as any document with specific purpose to achieve something and approved by competent authority. Social policies are meant to address social issues such as poverty, education, health, housing, land and so on. As mentioned above these policies are important to tackle the issue of poverty. Poverty has become a central concern in the development discourse of present time both at global and local level. Addressing the issue of poverty involves many different factors of development, as this is a multidimensional and complex issue. Poverty is not only about economic growth but also covers social, political, cultural and other factors. For example, only distribution of subsidised food to poor people cannot bring sustainable solutions for the reduction of poverty. It 
involves other aspects of development such as health, education, income, employment, gender, culture and so on. Hall et.al. (2004) say that the best hope of raising standards of living and eradicating poverty lies in an approach that combines a commitment to economic development with the introduction of social policies that specifically and directly address the poverty problem.

Therefore, social policies can play a significant role in poverty reduction and alleviation. The social policies for health need to design and focus for the easy access to poor people. Similarly, education policy, land policy and economic policy need to design for giving the high priorities to poor for their benefits. In the context of Nepal there have not been designed and focused policies to poor people from the beginning. Most of the people live in rural areas and depend on agricultural work as I discussed. Most of the rural people are deprived from the fundamental basic needs. Rural poor people have not access to health, education, income, employment and so on. Moreover, there are not better policies for these kinds of services to the rural poor people. Due to these problems there has been huge number of people migrating day by day from rural areas to urban and other countries. A brief history of social policies in Nepal can be summarised in three different time period Rana Rule 1847-1951, after revolution of 1950-51 during Panchayat ${ }^{1}$ period (1951- 1990) and after the restoration of democracy (Post 1990).

During Rana rule of 104 years (1847- 1951) there were virtually no policies on the social sectors. The regime was based on dictatorial family oligarchy and the rulers of that time were in the view that if the people were provided with education and other services the level of awareness increases and they may raise voice and action against the regime. During this time the country was totally closed for outside world and the rule was severely repressive. However there were some policies pertaining to bureaucracy

\footnotetext{
${ }^{1}$ The party less political system that lasted for three decades (1960-1990) and overthrown by popular movement of 1990. At this time there was absolute monarchy and party activities were banned.
} 
and others to make sure that their absolute rule was under no threat. A basic legal code was also introduced to maintain law and order and legal system, which is considered to be based on caste system and Hindu religion. Although the state mechanism was the same there were some relatively liberal ruler who introduced some policies in the filed of taxation, Sati ${ }^{2}$ system and to some extent on education during later part of their rule. Regarding the poverty alleviation there were no policies at all during Rana regime. This rule was overthrown in 1951.

During Panchayat system a large number of social policies were formulated. A new constitution was promulgated in (1962) focusing on party less system of governance with the broad goal of creating exploitation free society through class co-ordination. This was followed by introduction of Muluki Ain (Civil code) emphasising on rule of law. Then in 1964 land reform act was introduced with the objective of equitable distribution of land and others like "back to the village" for rural development, establishment of Agricultural development bank, co-operatives, new education policy were formulated in 1975 and the primary education was made free in 1977. However these policies were not genuinely put into practice. After the restoration of multi party democracy in 1990, the popularly elected governments made significant changes in social policies. Economic liberalisation, introduction of some acts such as co-operatives act, Forest act giving local autonomy, health and education policies, and in 1995 the government promulgated a new policy called Lets Build Our Village Ourselves (LBOVO) giving funds as well as authority to locally elected bodies. This was a milestone in the poverty reduction strategy.

Therefore, good policies and effective implementation are significant to achieve and overcome the desirable impact. There have been successful experiences of the government social policies in other countries. For example, according to Kambhampati (2004), "the experience of countries like Sri Lanka and China has shown that appropriate government policies can help

${ }^{2}$ A social system where widow of the deceased was to be burnt alive with her husband, this system was abolished in late 1920s. 
to increase both literacy and life expectancy.”(p. 233). To gain this achievement Sri Lanka has been implementing an effective medical care facilities and system for their population. Similarly China achieved a remarkable transition in health and nutrition. Rahnema(1992 p. 165) makes clear that, "The need for more diversified and expanded services has led many of these programmes to reserve a leading place to sectoral reforms, particularly in such areas as unemployment, population control, co-operatives, and educational and health services.”

For reducing and alleviation of the poverty, it is very important to reform the different sectoral development of social policies that are the main roots of the change into society. As Shepherd points out, "Sustainable agriculture, through its greater share of income accruing to labour and its greater labour intensity, and the affirmation and development of common property and services, with equity considerations as part of the equation, will alleviate poverty.” (1998 p.94). Unless these kinds of different services and opportunities provided to poor people, there is not hope to reduce and alleviation of poverty.

\section{In the Name of Poverty Alleviation}

I have been working for International Nepal Fellowship (INF), a nongovernmental organization working in the filed of community health and development. In the following case study I want to highlight one programme in the name of poverty alleviation. This story was collected from Mugu one of the poorest and remotest districts of Nepal.

In May 2002, I was walking in a village in order to do the follow up work of my organisation in the nearest village of the district headquarters of Mugu. I met three people who were harvesting wheat. The harvest was good and I asked them who the crop and land owned. To my surprise they replied 'neither the crop nor the land is ours, we are just working here'. I asked them again if so how much wages they get. "We do not have salt for household consumption so if we do whole day work here then we get one kilogram of salt 
from the landlord. I wondered that how the local rich people have exploited the innocent poor since the subsidised rate of one kilo salt is only Nepalese rupees (NRs) six whereas the wages of the day is NRs. 100. Do not you know that the government has been providing the salt and rice in subsidised rate in this district for many years? 'Yes, we know helicopters bring rice and salt in this district and we also do carry that stuff from there to government office and then to rich people's house, government gives only to rich people and we do the work and get from them”.

In fact it was an aid from World Food Programme in support of government's poverty alleviation strategy. It is ironic to know the target people themselves view this programme in this way. Instead poor people are working more than 15 times extra work to get those subsidised items which were really meant for them. Under this circumstance of exploitation and deprivation one can easily understand the outcome of poverty reduction scheme. This real story characterizes the way rural poor have been becoming poorer and the rich getting richer in the name of development, especially poverty reduction. The question arises can such practice or implementation of poverty reduction programme bring betterment in the lives of rural poor whatever better the social policies are. Poverty reduction strategy rests on three legs: opportunity, empowerment, and security" (World Bank 2000). In above story, where do we find these important components?

\section{Conclusion and Implications}

Poverty is a major factor that brings obstacles in any kind of growth and development. When people suffer from poverty then they may have affected in various kinds of problems, as the poverty is multidimensional. It is not only associated with economic problems but it also affects other aspects such political, social and cultural and so on. Any policies that can have impact on social lives of people can be called as social policies. As discussed above social policies have great role to play in the reduction of poverty in the given society. It is clear that the social policies of China and Sri Lanka have good impact and achievement on improvement of the people's health. A better social policy of the country can provide various opportunities to 
the poor people for reducing their poverty. However, formulation of better policies alone is not enough to tackle the multifarious problems of poverty but that need to be genuinely put into practice which has been found significant in many developing countries including Nepal. It is significant that the social policies should be based on the need and interests of poor people, should be explicit and effectively implemented. Therefore, to stop and correct these problems need effective social policies. It is clear that social policy can have a direct impact to reduce and alleviation of the poverty.

\section{References:}

Allen, T. and A. Thomas (2000). Poverty and Development into the $21^{\text {st }}$ Century, Oxford University Press.

Burkey, S. (1993) People First, A Guide to Self-reliant, Participatory Rural Development. Zed Books Ltd. London

Escobar, A. (1997) “The Making and Unmaking of the Third World Through Development” in Rahnema, M. and Bawtree, V. (eds) The Post Development Reader, Zed Books, London pp. 85 - 93

Hall, A. and Midgley J. (2004) Social Policy for Development, SAGE Publications Ltd, London

Kambhampati, Uma S. (2004) Development and the Developing World, Polity Press, Cambridge UK

Latouche, S. (1997), "Paradoxical Growth”, in Rahnema, M. and Bawtree,

V. (eds), The Post Development Reader, Zed Books Ltd. London pp. $135-142$

Nalli, S. (2005), “The Manifesto for Global Justice: Millennium Development Goals” Drishtikone A Quarterly Newspaper, Evangelical Fellowship of India Commission on Relief Publication, New Delhi, Dec. 2004 - March 2005, pp. 3-6

Rahnema, M. (1992) "Poverty” in Sachs, W. (eds) The Development

Dictionary, A Guide to Knowledge as Power, Zed Books Ltd. London, (pp.158-176).

Shepherd, A. (1998) Sustainable Rural Development, Machillan Press Ltd. London 